\title{
ISSUES
}

\section{0 \\ The impact of the \\ Reconciliation, Tolerance and Unity Bill on the 2006 election}

\section{Mosmi Bhim}

'The re-election of the Soqosoqo Duavata ni Lewenivanua-led government hinges on the success of the Promotion of the Reconciliation, Tolerance and Unity Bill... If the Bill goes down, the government goes down with it.' So said Fiji's Attorney General Qoriniasi Bale, a key ally of the Prime Minister, at a public meeting on 15 June 2005. ${ }^{1}$ That comment, a year prior to Fiji's May 2006 general election, indicated the great political importance attached by the government to legislation ostensibly aimed at bringing closure to five years of police investigations, settling differences between the victims and aggressors of the May 2000 coup, and establishing a framework for greater harmony between the country's 55 per cent indigenous Fijian and 40 per cent Indo-Fijian communities. Yet, from the time the Promotion of Reconciliation, Tolerance and Unity (RTU) Bill was first mooted, tensions between the Soqosoqo Duavata ni Lewenivanua (SDL) and the major Indo-Fijian party, the Fiji Labour Party (FLP), and between the government and the Republic of Fiji Military Forces (RFMF) were gravely inflamed by the proposed new legislation. Opponents saw the amnesty provisions in the Bill as a dangerous concession to Fijian nationalist opinion, and as potentially entailing the release from prison of 2000 coup leader, George Speight, and of prominent chiefs convicted for coup-related offences. Despite so explicitly pinning its electoral fortunes to the fate of the Bill, after months of great controversy, the government eventually chose to shelve the 
Bill shortly before the 2006 election, declaring its intention instead to revisit the issues thereafter.

This chapter looks at why the government chose to introduce such controversial legislation in the run-up to the 2006 poll. It examines first the provisions of the Bill, and why, five years after the coup (rather than in its immediate aftermath), political difficulties arose that prompted resort to parliamentary legislation on the amnesty issue. In order to address that question, it is necessary to revisit the events of May-November 2000, and consider the coup-related offences committed at that time. The chapter then considers the positions of the government and other supporters, as well as the objections of opponents, including the FLP and the RFMF, and reviews the documentation arising out of the joint parliamentary select committee that was convened to deliberate on the proposed legislation. Finally, it considers why the RTU Bill was eventually deferred, prior to the 2006 election, and whether or not it nevertheless achieved important objectives for the SDL election campaign.

\section{The provisions of the RTU Bill}

The idea of a reconciliation Bill was first raised in August 2004, and the fully drafted Bill was introduced on the floor of parliament on 31 May 2005. The Bill provided for the establishment of a Reconciliation and Unity Commission with powers to conduct inquiries and to facilitate the granting of reparations, compensation and amnesty. The conduct of the inquiries, the Bill specified, would also take into account the traditional Fijian principles of restorative justice. Two committees were to be established - a Victims and Reparations Committee, responsible for granting reparations and compensation, and an Amnesty Committee, empowered not simply to release prisoners, but also to nullify the original convictions. Both of these committees were to have three members, who would deliberate on applications made and submit reports to the commission. In addition, a National Council for the Promotion of Reconciliation, Tolerance and Unity was to be established and entrusted with developing strategies for the promotion of greater understanding between the two major racial communities.

Of the 36 clauses contained in the RTU Bill, the longest was clause 21, titled 'Applications for Amnesty', which had 15 sub-clauses. It allowed those 
convicted of coup-related offences that were classified as 'politically motivated' and committed between 19 May 2000 and 15 March 2001 to apply for amnesty. 'Politically motivated' activities were to be distinguished from those of a 'criminal' nature, a proposal which generated obvious difficulties: 'treason', for example, is usually highly politically motivated but nevertheless usually also considered the most severe form of criminal activity against the state. The intended application of the Bill to the 2000 coup-related prisoners was explicit, and the four clauses relating to this indicated some urgency in securing the release of prisoners on the part of government. The four clauses were:

(2) In dealing with applications for amnesty, the Commission shall give priority to applications from persons in custody...

(6) If an applicant for amnesty is charged...or is standing trial...the Commission may request the court to postpone the criminal proceedings pending the consideration and disposal of the application for amnesty...

(12) Any person who has been granted amnesty...shall be released from prison forthwith on a warrant issued by the President...

(13) An amnesty granted by the President...shall have the effect of erasing the conviction. $^{2}$

The final reference to 'erasing the conviction' provides further insight into the objective of the RTU Bill. The 1997 constitution potentially already provided the government with the means, via a Prerogative of Mercy Commission, to grant 'pardons' to chiefs and others imprisoned for coup or mutiny-related activities. Indeed, that Commission had been convened to commute a death sentence for George Speight to life imprisonment. ${ }^{3}$ But amnesties, unlike pardons, wipe out the stain of the preceding conviction, a matter of no small importance for Fiji's status-oriented convicted chiefs, as shown in the next section.

\section{Why was the RTU Bill introduced?}

By 2005, the government had a number of good reasons for wanting to bring an end to the coup-related court cases. Fiji could not continue, forever, to thrash over the events of 2000. The Police Commissioner, Australian Andrew Hughes, would have liked to have finished the coup investigations before the 2006 elections. ${ }^{4}$ In a statement to the media after introducing the RTU Bill in May 2005, Prime Minister Laisenia Qarase said the main purpose of the 
intended legislation was to bring closure to the turbulent era following the 2000 coup:

It will enable us to more effectively concentrate on nation-building, strengthening our economy and improving living standards, especially for the poor...The long delays in completing investigations are evidence that our law enforcement authorities are having difficulty coping. This is an issue of great concern... The concept of restorative justice is not new to Fijians. It is built into their culture. The whole community becomes involved in finding solutions and imposing sanctions. This is reflected in various customary practices such as veisorosorovi ${ }^{5}$ and matanigasau. ${ }^{6}$

Such appeals to traditional or customary ideals of reconciliation, however, were questioned by others, such as Citizens Constitutional Forum activist Jone Dakuvula, who suggested that Fijian rituals of veisorosorovi and matanigasau are customarily undertaken only after there has been prior agreement between the perpetrator and the victim. The offender cannot force the offended to accept matanigasau. Mr Dakuvula said the government's proposed Reconciliation and Unity Commission was not a genuine product of reconciliation because the victims had not been consulted.?

The Qarase government's Ministry of Multi-Ethnic Affairs and National Reconciliation and Unity, which sought to promote the ideals of Christian forgiveness, harmony and cooperation as a way forward for Fiji, came to play a central role in promoting support for the RTU Bill. The government declared 4-11 October 2004 as 'Reconciliation Week', to coincide with Fiji's independence day on 10 October. The Tui Cakau and Lands Minister Ratu Naiqama Lalabalavu led a matanigasau ceremony at Albert Park, Suva, at which 20 tabua (whale teeth) were presented to seek forgiveness from the parliamentarians held hostage during the 2000 coup. He was accompanied by Naitasiri chief Ratu Inoke Takiveikata, Bau chief Ratu Tanoa Cakobau and Ratu Inoke Seniloli, the younger brother of imprisoned Vice President Ratu Jope Seniloli. ${ }^{8}$ It was an act of contrition viewed by many as hypocritical. Deposed Prime Minister Mahendra Chaudhry and the MPs held hostage in 2000 were not present to receive the matanigasau. Very few Indo-Fijians attended the event. Nevertheless, the themes of 'reconciliation' and 'forgiveness' struck a chord within predominantly Christian Fijian communities and seemed, for the government, to provide a means of mobilizing support for nation-building 
and perhaps also a means to marginalize critics in the FLP, who could thereby be accused of unwillingness to reconcile and forgive those who had, it was to be publicly acknowledged, done them such great injustice at the time of the May-July 2000 disturbances. This set the tone for the deliberations on the RTU Bill.

In order to fully appreciate the context of the RTU Bill, it is necessary to revisit the events surrounding the 19 May 2000 coup. On that day, George Speight had led a group of gunmen to seize control of Fiji's parliament, deposing the government of Fiji's first Indo-Fijian Prime Minister, Mahendra Chaudhry. The insurrection had coincided with a taukei march through Suva; some 15,000 people took to the streets of the city, greatly outnumbering police officers. A total of 167 shops were looted, 15 shops and five kiosks burnt down and 269 people arrested in the rampage, with total damage costs estimated at $\$ 30$ million by then Police Commissioner Isikia Savua. ${ }^{9}$ Around 7,500 people were to lose their jobs as a result of the 2000 coup. $^{10}$

The day after the coup, inside parliament, Bau high chief Ratu Jope Seniloli swore in a rebel prime minister and cabinet - many of whom were later to be convicted for taking an illegal oath. For the next 56 days, members of parliament from the government side, including Prime Minister Mahendra Chaudhry, were held hostage inside the Veiuto complex. They were surrounded by a human shield of supporters, who drank grog, ate and sang in the grounds of the complex, where they also did their laundry and cooking. ${ }^{11}$

Military commander Frank Bainimarama was far away in Lebanon on the day of the coup, but cut short his trip upon hearing of events in Suva. ${ }^{12}$ Speight and his group had hoped to trigger full backing from the RFMF, but, instead, the military encircled the complex, commencing a protracted siege. Soldiers were reluctant to move into parliament for fear the rebels might carry out their threat of injuring the hostages. ${ }^{13}$

Despite the loose cordon thrown around parliament, Speight and his followers were able to move in and out with comparative ease. A state of emergency was declared on 27 May 2000, but to little avail. That night, rebels marched through Suva and trashed the Fiji TV headquarters, threatening also to march on the President's residence. 
Reportedly in response, on 29 May, the military commander asked the then president of Fiji, Tui Nayau Ratu Sir Kamisese Mara, to step aside. Bainimarama assumed executive authority, and issued a decree to abrogate the constitution. Thereafter, the army strengthened its presence around Suva and oversaw negotiations with the rebels. Daily curfews were imposed, lasting from sunset until sunrise. The city suffered power cuts over the 56-day siege, as a result of the sabotage of the Monasavu dam, the key hydro-electric power source for Viti Levu. Speight and the rebels also encouraged takeovers of police stations and the setting up of roadblocks in other parts of the country. Victimization of Indo-Fijian communities occurred in areas such as Muaniweni, Naitasiri, Dawasamu in northern Tailevu and Dreketi near Labasa, where farms were looted, Indo-Fijian villagers threatened and cattle killed. Fears that the coup might trigger a bloody split in the RFMF seemed realized after a mutiny at the Sukunaivalu Barracks at Labasa, on Fiji's second largest island Vanua Levu, in July 2000.

Eventually, top military officers' efforts to reach a settlement bore some success. Signed on 9 July 2000, the Muanikau Accord promised to address the political demands of the coup perpetrators and to give them an amnesty in exchange for the release of the hostage parliamentarians and the return of all weapons. The remaining hostages - including the deposed prime minister, Mahendra Chaudhry - were released by 13 July 2000.

Although the rebels vacated parliament, instead of disbanding they shifted to the Kalabu Fijian School on Suva's outskirts, and continued to destabilize the country. The military lost patience. George Speight, together with his lawyer Tevita Bukarau, his media advisor Josefa Nata and his personal bodyguard, known only as 'Cakau', were arrested on the night of 26 July 2000 at the Laqere Bridge, for failing to stop at a military checkpoint and for carrying illegal weapons in violation of the Muanikau Accord. ${ }^{14}$ The next day, the army stormed the Kalabu school, in an operation which resulted in the death of one rebel and 32 casualties, and the arrest of key figures, such as the rebel strategist Colonel Ilisoni Ligairi and Josefa Savua, the brother of Police Commissioner Isikia Savua. ${ }^{15}$ Altogether, 415 people were arrested. Others captured included Lieutenant Colonel Rusiate Korovusere, former Fiji Intelligence Services boss Colonel Metuisela Mua and Rewa MP Ratu Timoci Silatolu. As had been the 
case for Speight, amnesty provisions were deemed inapplicable because the rebels were carrying illegal weapons.

Four months later, the country appeared to be moving back to normality. But then, on 2 November 2000, a mutiny by rebel soldiers took place at the Queen Elizabeth Barracks in Nabua - not long before the date for a scheduled court hearing for George Speight. Commander Bainimarama narrowly escaped an attempt on his life. Mutinous soldiers from the Counter Revolutionary Warfare Unit (CRWU) killed three unarmed regular soldiers as the mutineers tried to take over the national operations centre. Five CRWU soldiers were later killed when loyalist forces recaptured the military camp. ${ }^{16}$ The incident left a legacy of bitterness and tension within the army, and helps to explain officers' strong hostility to the RTU Bill.

Aside from wanting to bring an end to the long-drawn-out saga of couprelated court cases, by late 2004 the government had become greatly concerned about the growing legal threat to Fiji's customary chiefs. The initial arrests of the so-called 'civilian coup' leaders back in 2000, and then of the soldiers who had played a somewhat more secretive role, had left many of the country's traditional chiefs untouched, although some were widely known to have

\section{Table 10.1 Police charges for offences committed during the 2000 civil unrest}

Unlawful assembly

Mutiny

Treason $^{1}$

Wrongful confinement

Arson

Robbery with violence

Incitement to mutiny

Damaging property

Shop-breaking and entering

Notes: ${ }^{1}$ Includes taking an illegal oath.

Source: Police information provided for Report of the Sector Standing Committee on Justice, Law and Order on the Promotion of Reconciliation, Tolerance and Unity Bill, November/December 2005, p.53-54. 


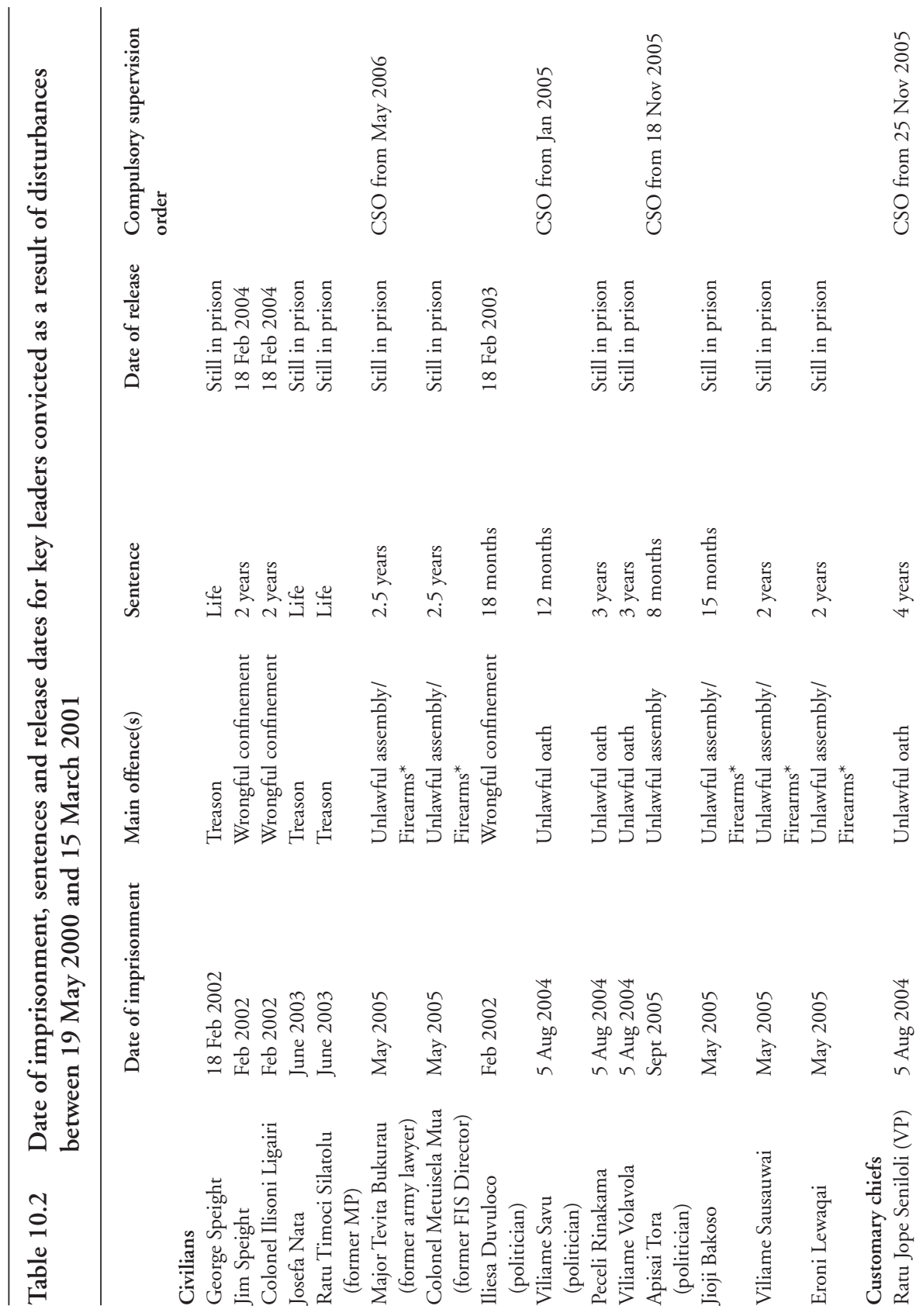




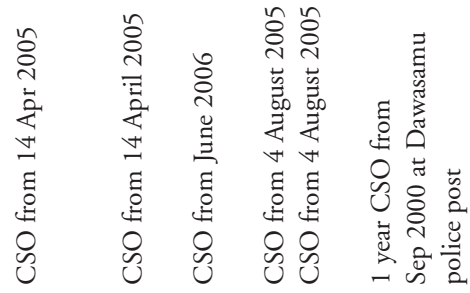

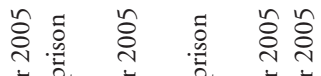

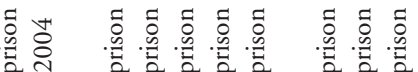

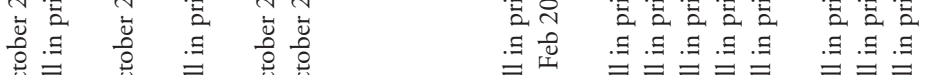

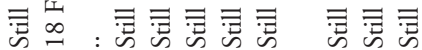

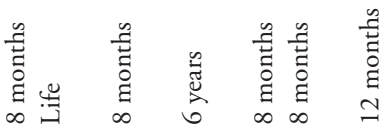

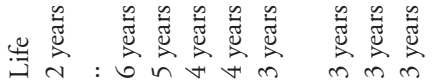

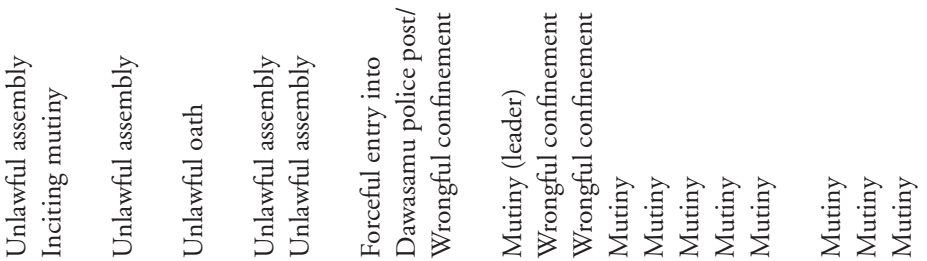

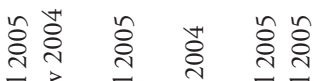

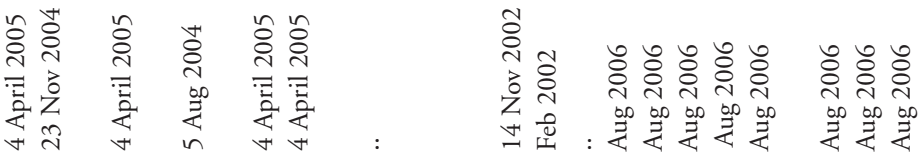

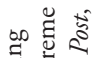

氙苛

ㅍำ

召兘这

일 ఫ

๘

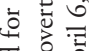

흘 तै

I 3

ญี

펄. 코

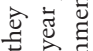

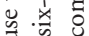

苂

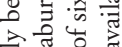

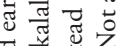

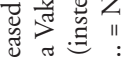

丞

氙 苛

E

象起

o $\Xi$

2.ㅇํㄹ

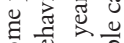

क ป :

बंँ

Сे $8 \cdot 5$

प्र 000

हี है है

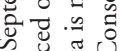

on

跣焉

范芯氙

苞宁

刍

겅

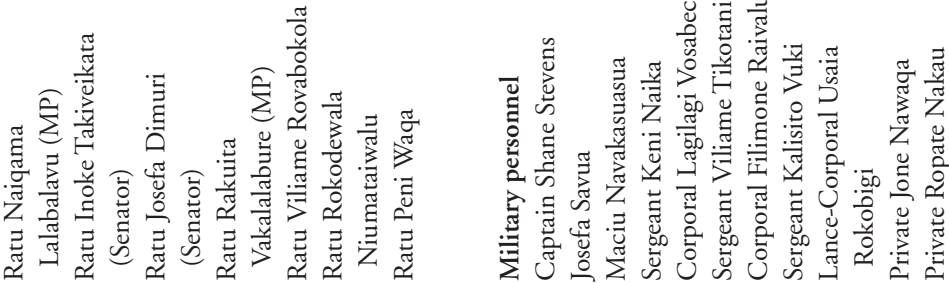

$\cong-\frac{1}{0}$

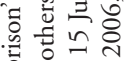

등

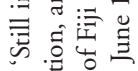

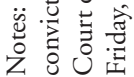


played a powerful behind-the-scenes role. By late 2004, however, the Director of Public Prosecutions Office had gathered sufficient evidence to launch such prosecutions. Vice President Ratu Jope Seniloli, along with Deputy Speaker of the House Ratu Rakuita Vakalalabure and three other chiefs were convicted on 5 August 2004 for taking an unlawful oath to be part of Speight's government on the day after the coup. ${ }^{17}$ Ratu Seniloli was sentenced to four years imprisonment and Ratu Vakalalabure to six years. ${ }^{18}$ On 23 November 2004, the Turaga na Qaranivalu, Ratu Inoke Takiveikata, the paramount chief of Naitasiri, was sentenced to life imprisonment for inciting mutiny in November 2000. In mitigation, Ratu Inoke, himself a former army officer, claimed that he had requested his backers to mount a non-violent takeover of the military camp, but this was not accepted by the presiding judge, Justice Anthony Gates.

Still more importantly, Minister of Lands and Tui Cakau Ratu Naiqama Lalabalavu was convicted for unlawful assembly during the takeover of the Sukanaivalu Barracks in Labasa between 4 July and 3 August $2000 .{ }^{19}$ In his defence, Ratu Naiqama acknowledged that he had entered the Sukanaivalu Barracks at the height of disturbances, but claimed to have been fulfilling traditional leadership responsibilities. He said he had been traditionally invited - along with the three other chiefs - by Tui Labasa Ratu Joseva Ritova Qomate to go to the barracks to ensure nothing unlawful was done. ${ }^{20}$ The three other Vanua Levu chiefs were Ratu Josefa Dimuri, Tui Nadogo Ratu Viliame Rovabokola and Tui Wailevu Ratu Rokodewala Niumataiwalu. All four, including Ratu Naiqama, were given eight month prison sentences; all four were admitted to Labasa hospital with alleged illnesses after serving one week of their sentences. Ratu Naiqama and Ratu Josefa were released within two weeks of their conviction on compulsory supervision orders to serve their sentences extra-murally. ${ }^{21}$ Ratu Naiqama served, in total, only ten days of his sentence before being released to serve the rest by doing community work at the Sacred Heart Catholic Cathedral in Suva. ${ }^{22}$ Six months later, in August 2005, Ratu Viliame and Ratu Rokodewala were also released on compulsory supervision orders. ${ }^{23}$

For Qarase, the arrest, conviction and imprisonment of such powerful customary chiefs posed a far-reaching challenge to the leadership within Fijian society: 
Police enquiries have so far implicated more than 2,500 citizens. A characteristic of the year 2000 law-breaking was that probably the majority of those involved were motivated by Fijian customary belief, tradition and duty...there was a clash of values between the old and the new, between the traditional communal system and one founded on the rule of law and individual human rights. A significant section of Fijian opinion felt those charged and convicted had been acting in furtherance of their traditional functional responsibility...they were seen to be responding to the cultural concept of the vanua - the chiefs, the people and the land.... The nation moved into uncharted waters when high chiefs were found guilty of coup-connected offences and sent to prison .... (this had) associated implications for social stability. ${ }^{24}$

There were also important political reasons why the prosecution and imprisonment of such important political figures posed difficulties for the Qarase administration. In the wake of the August 2001 general election, Qarase's SDL had formed a coalition government with the Conservative Alliance-Matanitu Vanua (CAMV). The SDL had gained 32 MPs, while the CAMV had six. Of these six, Speight had been convicted - and, at a by-election, replaced by his brother, Samisoni Tikoinasau - and both Deputy Speaker Ratu Rakuita Vakalalabure and Ratu Naiqama had been given prison sentences. ${ }^{25} \mathrm{At}$ the time of his imprisonment, Ratu Naiqama was not only Minister of Lands: as Tui Cakau, he was also the paramount chief of Cakaudrove, and thus leader of Tovata, one of Fiji's three traditional confederacies. Perhaps most importantly of all, he was president of the CAMV. The imprisonment of such a senior figure in the government threatened to break up the SDL-CAMV coalition, which at least in theory might have resulted in an early election. In such circumstances, Fijians might have gone to the polls deeply split, with the consequence that the SDL might have lost.

That the threat of a split was at least plausible was indicated by the revelation that, shortly before the government's introduction of the RTU Bill, the CAMV had plans to introduce legislation of its own. CAMV MP Samisoni Tikoinasau indicated that CAMV parliamentarians intended to table a motion in parliament for the government to grant immunity to coup perpetrators. ${ }^{26}$ This was not the first time that the CAMV had requested a pardon for imprisoned coup leaders. After Ratu Jope's conviction on 5 August 2004, Ratu Naiqama reiterated the CAMV stance that all those charged with coup-related offences should be pardoned, as after the 1987 coup. ${ }^{27}$ Tikoinasau had demanded the 
Great Council of Chiefs do something about Ratu Jope's conviction, and stated that the matanigasau performed in 2000 to seek forgiveness should have been given legal recognition. Tikoinasau also questioned why army commander Bainimarama had not been charged for abrogating the constitution and removing then president Ratu Mara. ${ }^{28}$ But the new threat to put the issue before parliament left the Prime Minister in some potential difficulty. Any vote on such a motion would have left the SDL with the dilemma of either siding explicitly and emphatically with the coup convicts or lining up alongside the FLP in opposing the Bill. Both courses of action would have been deeply damaging for the government.

Qarase was intent on assuaging these potential frictions in his governing coalition, and on preserving 'Fijian unity'. Ratu Naiqama had resigned on 7 April 2005, and was replaced by Tikoinasau as Minister of Lands. ${ }^{29}$ Earlier in the year, Cakaudrove East constituency MP Manasa Tuqia had been appointed deputy speaker, after Ratu Rakuita lost his West Cakaudrove parliamentary seat as a result of missing two parliamentary sittings due to his imprisonment. ${ }^{30}$ That the SDL was being cautious in managing its relations with the CAMV was demonstrated by the SDL's decision to not field any candidates for the Cakaudrove West by-election in June 2005, resulting in an unopposed win by CAMV's Niko Nawaikula, a lawyer and former Native Lands Trust Board official. ${ }^{31}$ Imprisoned CAMV chiefs were quickly welcomed back into the government upon their release. Ratu Josefa Dimuri returned as a senator and secretary general of the CAMV. Ratu Naiqama was appointed as the new Transport and Shipping Minister on 21 September 2005, after completing his prison term. ${ }^{32}$ Unlike Speight and Vakalalabure, he did not lose his seat as a result of serving a prison term because the law insists on disqualification only if the sentence is more than 12 months. ${ }^{33} \mathrm{He}$ had been convicted for only eight months, and had had his prison term reduced to six months for good behaviour. Nevertheless, for Ratu Naiqama, the prison sentence was thought to have been harsh and unjust. After being released from prison, Ratu Naiqama reiterated in parliament that he and three other chiefs entered Sukanaivalu Barracks in July-August 2000 on the request of the police and military.

As a traditional leader, I take slight that, at times, our traditional authority [has] been abused and exploited by the powers that be... During the 2000 crisis in Labasa, the late Tui Labasa 
and I, amongst a few other Vanua Levu chiefs were approached, both by the Police and Military to intercede in the face-off between the soldiers at Sukanaivalu Barracks.... had it not been for our positive contribution, Labasa would have been looted, burnt and soldiers would have been killed and probably maimed each other. Yet, when all was brought to normal, we were charged and convicted for offences against the Public Order Act. Here, Sir, is an example of abuse of our traditional authority .... For me as Prisoner Number LB32/05 at Vaturekuka is something I will live with for the rest of my life, without any regret or shame because...I know that what I did then was right. ${ }^{34}$

Despite the protestations to the contrary, the stain of being found guilty in such a way clearly was not regarded lightly in Fiji's status-oriented chiefly order.

There had also been political risks associated with the conviction of senior figures within the SDL itself. Ratu Inoke Takiveikata, for example, was the founding president of SDL, a government senator and, although by 2006 behind bars, remained the vice president of the governing party. SDL member for Lomaiviti, Simione Kaitani, was also dragged before the courts, although ultimately found not guilty; and new revelations suggested a threat to senior SDL ministers, such as Konisi Yabaki and Savenaca Draunidalo. Coup convict Maciu Navakasuasua had also named Ratu Epeli Kanaimawi (a senior figure in the Assembly of Christian Churches in Fiji), Pastor Poate Mata and then Methodist Church president Reverend Tomasi Kanailagi as supporters of the coup. ${ }^{35}$ Army officer Viliame Seruvakula (at the time serving as an instructor with the New Zealand army) revealed being offered a bribe of $\$ 250,000$ to support the 2000 takeover, and implicated still more senior figures in couprelated crimes. Although the seriousness of the offence for which Ratu Inoke Takiveikata had been convicted ruled out his early release, the evident sympathy of the Prime Minister for his imprisoned ally was shown by his regular private visits to Korovou prison to brief Ratu Inoke on 'the state of the SDL party and issues of political and national importance'. ${ }^{36}$

\section{The opposition position}

The RTU Bill generated strong opposition among Fiji's citizens, and from the leaders of neighbouring metropolitan powers. While the main supporters of the Bill were Fijian politicians, parties, provincial councils and related groups such as the Methodist Church and Fijian trade unions, those opposing the Bill 
were the disciplined forces, Indian religious groups, professional organizations, foreign governments and organizations, most civil society organizations, most of the non-Fijian political parties, and some of the Christian churches. Amongst the representatives of the Fiji Indian community, the Bill generated almost blanket condemnation, particularly from those who had been victims of the 2000 coup and held hostage at the parliamentary complex. Many of the country's European and part-European politicians opposed the Bill from a legal or human rights perspective, as did the bulk of non-Fijian lawyers.

Opposition leader Mahendra Chaudhry initially called on Prime Minister Qarase to resign because stakeholders, including political parties, religious bodies, and non-governmental organizations (NGOs) had not been fully consulted about the Bill's provisions. Chaudhry said the real purpose of the Bill was to free political prisoners and that this would mean legalizing terrorism. ${ }^{37}$ The smaller, mainly Indo-Fijian backed National Federation Party (NFP) described the Bill as a catalyst for further political instability, and as likely to widen the racial divide and so derail economic recovery. ${ }^{38}$ The leader of the United Peoples Party, Mick Beddoes, also claimed inadequate consultation. ${ }^{39}$ Chaudhry later said he might support the Bill if it were substantially re-written to facilitate genuine reconciliation. Truth-telling, modelled on Bishop Desmond Tutu's activities in the South African Truth and Reconciliation Commission, needed to be a core component of the process, enabling perpetrators of couprelated crimes to divulge information about the events of May 2000 and the secretive backers of the coup. ${ }^{40}$

Overseas reactions were tempered by reluctance to interfere in Fiji's domestic affairs. Australian Minister for Foreign Affairs Alexander Downer said 'the army commander had no business in politics and should stick to his job - running the military. ${ }^{41}$ His New Zealand counterpart, Phil Goff, was more critical of the government, criticizing the idea that 'people who have overthrown a democratic government by force may be exempted from the category of criminals if it was done for political reasons' ${ }^{42}$ He urged Prime Minister Qarase to amend the controversial amnesty provisions. The US Ambassador to Fiji, David Lyon, expressed concern about the amnesty section saying that a coup culture had developed in Fiji since 1987 that was detrimental to Fiji's reputation and would have a negative impact on investment, tourism and the 2006 elections. ${ }^{43} \mathrm{~A}$ 
Tebbutt poll of 1,008 people found that 44 per cent of residents were against the Bill, 35 per cent were for it and 12 per cent did not care. ${ }^{44}$

Opposition was expressed by regional and international government bodies and NGOs. The European Union, local NGOs - such as the Citizens' Constitutional Forum, Women's Action for Change, the Ecumenical Centre for Research Education and Advocacy, and the Fiji Women's Rights Movement - protested against the Bill, saying it breached UN human rights conventions. The Fiji Cane Growers' Council and the National Farmers Union expressed opposition. ${ }^{45}$ Fiji Public Service Association general gecretary Rajeshwar Singh claimed solid opposition by trade unions around the world. ${ }^{46}$ The International Confederation of Free Trade Unions wrote to the Fiji Prime Minister expressing apprehension about the RTU Bill, and was particularly alarmed by the amnesty provision for coup perpetrators. ${ }^{47}$

The Fiji Police Force opposed the Bill on the grounds that the amnesty provision would interfere with the authority of the Police Commissioner to investigate offences and prosecute offenders. The military, as discussed in more detail in the next section, likewise opposed the Bill on security grounds, expressing anxiety that the amnesty provisions would legitimize terrorism. ${ }^{48}$ The Fiji Law Society opposed the Bill on the grounds that some of its provisions were unconstitutional and that granting of amnesty would erode and have a harmful effect on the role of the judiciary. Such a law, it said, would retrospectively license terrorism, was a recipe for instability and would interfere with the powers of the Director of Public Prosecutions. The society warned against improper use of customary law and tradition for political gain; society president Graham Leung reminded the government that 'no culture, no religion and no government are above the law'. The International Commission of Jurists said the amnesty provision appeared incompatible with international law and insisted that it be amended so as not to violate Fiji's obligations under international human rights law. The Human Rights Institute of the International Bar Association expressed reservations that the Bill would be able to deliver the 'reconciliation' that it promised. ${ }^{49}$

The outcry amongst civil society organizations, political parties and international donors and diplomats came as a surprise to Qarase and Attorney General Qoriniasi Bale, who acknowledged the need for further consultation 
and declared an intention to consider substantial amendments to the Bill. The Prime Minister assured the public that, given the strength of the public reaction, the Bill would be reviewed: the report of the sector committee entrusted with examining the proposed legislation was to play a major role in determining the final draft. The government also promised to ensure that the final legislation met the requirements of the constitution and did not compromise the Office of the President. ${ }^{50}$

\section{The military position}

The RTU Bill exacerbated a previously existing rift between the government and the RFMF. The impasse between the military commander and the government had been ongoing since 2001. Frictions between the military and the government had forced the latter to change key position-holders in the Home Affairs Ministry two times - Home Affairs Minister Jonetani Cokanasiga was relegated to the back benches in December 2004 and replaced by Josefa Vosanibola; and Home Affairs CEO Jeremaia Waqanisau was transferred to an ambassador's post in China in January 2004. The commander also distrusted the new Home Affairs CEO, Dr Lesi Korovavala, and was later to hold him responsible for the stand-off between the military and the government in January 2006. The military then alleged that Korovavala and Prime Minister Qarase had encouraged Lieutenant Colonel Jone Baledrokadroka to incite a mutiny in that month. ${ }^{51}$ The government had initially appeared reluctant to extend Bainimarama's contract in February 2004, but President Ratu Josefa Iloilo had decided to renew his term in office on 29 January $2004 .{ }^{52}$

For the RFMF, the RTU Bill was seen as a threat to its efforts to stabilize the security situation in the aftermath of the 2000 coup. RFMF commander Frank Bainimarama had faced a personal threat to his life during the November 2000 mutiny. He had purged senior commanders with suspect loyalties, often keeping them close to military headquarters at Berkeley Crescent in positions without major responsibility. Top commanders believed that the Bill would derail their efforts to bring to justice those responsible for the insurrections of May and November 2000.

The military conducted a succession of long-drawn-out trials from 2001. By April 2005, 159 sentences had been handed down: 58 soldiers had faced 
court martial for their role in the 2000 parliamentary takeover, 63 were tried for the takeover of the Sukanaivalu Barracks in Labasa, and the remainder were convicted for their part in the bloody mutiny of November 2000 and other coup-related offences..$^{53}$ The military refused to accept back into employment any of the convicted soldiers. The RTU Bill was viewed as likely to reverse efforts to bring those responsible for insurrection to justice. Even existing practices, such as the release of coup convicts under compulsory supervision orders, were strongly opposed by the commander. Bainimarama pointed out that the government was not only allowing people tainted by coup allegations to go free; they were 'even getting plush government jobs and diplomatic postings'. This, he argued, was creating a generation of criminals with no respect for the rule of law. ${ }^{54}$

Secondly, the formation of the Qarase government had, originally, been a military initiative, and the commander felt that ministers owed some loyalty to those who had put them into office. In the wake of the May 2000 upheaval, Qarase had headed an 'interim administration', with former military commander Ratu Epeli Nailatikau as deputy prime minister. It had not been intended as a permanent fixture. Originally, these interim leaders were apolitical technocrats, thrust into office to stabilize the political situation. That the government was characterized by appeasement of the nationalists combined oddly with their apparent support for the upholding of law. This was a contradiction expressed in the regular refrain that the Prime Minister supported the coup goals, but not its means. Comprised of realist politicians, the SDL realized that the support of the nationalists was crucial if it were to win. Only in 2001, in the wake of a court ruling rendering the government illegal, did Qarase reconstitute some parts of the group, first as a 'caretaker' cabinet, and then as the core of the new SDL party. In the process, the commander believed, the government had lost sight of its original mandate and proved itself to be in thrall to nationalist extremist demands.

The military's formal submission to the parliamentary select committee entrusted with undertaking hearings on the proposed legislation stated:

The Bill is ill conceived and is a recipe for internal conflict, unrest and violence. It is discriminatory and will breed ethno-nationalism... bring about despair, hopelessness and insecurity amongst the people as well as promote greater racial division. The majority of 
the offences committed during the period were predominantly by the indigenous race (offender) against those of Indian descent (victim); it will allow for the pardoning of the indigenous offenders versus the interests of the victims, thereby breeding the ideology of ethno-nationalism that is detrimental to the safety and well being of our society. ${ }^{55}$

The conviction of Ratu Inoke Takiveikata for inciting and aiding the November 2000 mutiny in which the commander narrowly escaped assassination sheds some light on why Bainimarama had been against the SDL since its formation in 2001. As discussed above, Ratu Inoke had called, so he admitted in court, for a peaceful takeover of the military camp. He had nevertheless later become the founding president of SDL and, even after his conviction, remained on close terms with the Prime Minister. This implied that, since its commencement, the SDL had prominently featured people who would have liked to have seen the army commander removed. That the threats to the commander in November 2000 were not confined to history also seemed, whether rightly or wrongly, demonstrated by the alleged attempted mutiny by acting land forces commander Colonel Jone Baledrokadroka on 12 January 2006, which Bainimarama claimed had been orchestrated by the government. ${ }^{56}$ Bainimarama refused to rule out overthrowing the government if the Bill were passed. ${ }^{57}$

Great Council of Chiefs' Senator Jim Ah Koy, businessman and former finance minister, echoed the commander's stance, explaining that 'his priority is national security and that is why he is coming out strong against the Bill'. ${ }^{58}$ Despite years of vociferous denunciation of the government, the commander succeeded in retaining his position at the helm of the RFMF. Close connections with the Office of the President placed the commander in a unique position. As the President was the appointing authority, according to one interpretation, the commander - although normally subject to oversight from the Home Affairs Ministry - was ultimately under the control of the President. The military also insisted that its 'reserve powers' under the 1990 constitution had not been superseded by the 1997 constitution. ${ }^{59}$ As a result, the commander believed he could securely speak out against the RTU Bill. Indeed, he vowed to continue doing so until the Bill was withdrawn. ${ }^{60}$ Bainimarama stressed that the RFMF would not take part in any reconciliation on the grounds that this would interfere with the military's discipline and court martial processes. ${ }^{61} \mathrm{In}$ 
addition to opposing the RTU Bill, the army had reservations about the Qoliqoli Bill and the proposed Bill on the Fijian courts. ${ }^{62}$ Nor was this oppositional activity confined to statements to the Fiji media. In the run-up to the 2006 election, the RFMF public relations team campaigned against the RTU Bill by distributing pamphlets ${ }^{63}$ and visiting rural areas to warn people about the Bill's disadvantages. ${ }^{64}$

\section{The government's reaction}

When the RTU Bill was introduced into parliament on 31 May 2005, the Leader of the House requested the Standing Orders be suspended to allow the House to deal with its first reading. In the public gallery, as if in a show of strength, military personnel sat quietly, closely observing the progress of the Bill through parliament. ${ }^{65}$ The Opposition Whip, the Hon. Krishna Datt, objected, saying the Bill contained certain provisions that were inconsistent and repugnant to the constitution of Fiji ${ }^{66}$ Instead of circulating the Bill to all 71 members of the Lower House 21 days before the next sitting of parliament, as required by law, the government had initially introduced it to the nine-member Parliamentary Business Committee, where it had a 56 per cent majority. ${ }^{67}$ For Datt, the consultation had been inadequate. Datt pointed to the strength of opposition to the Bill around the country, emphasizing the concerns expressed by the president of the Fiji Law Society and the director of the Fiji Human Rights Commission. Nevertheless, the Speaker allowed the suspension of Standing Orders to allow the first reading of the Bill before the House.

The second reading, on 2 June, occurred at the Nasese police headquarters amid tight police security. Military observers turned up again in the public gallery to show their disapproval. The FLP members walked out of parliament in protest, with FLP deputy leader Poseci Bune hand-signalling an imminent RTU Bill-related electoral reversal of the positions of government and opposition as he departed the chamber with his colleagues. The sole remaining opposition $\mathrm{MP}$ voicing concern about the Bill inside the house was Ofa Duncan. Outside the makeshift and temporary parliament at Nasese, NGOs and concerned citizens protested against the Bill. ${ }^{68}$ Many wore black in protest and lined the Nasese seawall holding placards. ${ }^{69}$ At the same time, in an unusual mobilization, the SDL's Jale Baba organized busloads of rural Fijians to stage counter- 
demonstrations in support of the Bill down near the Nasese seawall. After the second reading, the Bill was referred to the Law and Justice Sector Committee, entrusted to listen to submissions around the country. The Hon. Manasa Tugia, CAMV MP from Cakaudrove East constituency, was appointed chairperson of the committee by the government on 6 June $2005 .{ }^{70}$

The government reacted to criticisms inside and outside parliament by reemphasizing that the fundamental objective of the Bill was to promote, not force, unity amongst the people of Fiji. 'It is to try and acknowledge that we are made up of many different races, cultures, customs, languages, religions and that we have been talking about the need for unity for decades and decades now', insisted the Attorney General. ${ }^{71}$ Qarase reiterated that there would be no general amnesty, and that the Bill was not intended to free those who used the coup for their own gain or other criminal intent. He said that the victims would have a new opportunity to seek justice through compensation. ${ }^{72}$ In comments that echoed the concerns of many of the domestic critics, Qarase insisted that one of the main reasons for the Bill was to find out exactly what motivated people to concoct and support the coups of 1987 and 2000..$^{73}$ He said that the government would embark on a wide-ranging consultation process and that it would take into account objections to the Bill, and make the necessary amendments. The Ministry of Multi-Ethnic Affairs and National Reconciliation and Unity held three workshops, in Suva, Lautoka and Labasa, to inform the Indian and minority communities about the Bill. ${ }^{74}$

In addition, the Prime Minister and Attorney General appeared before an 'open forum' at the University of the South Pacific's marine studies campus, again promising amendments to the Bill, and facing down criticisms. The view was expressed at the forum that pardoning criminals could dissipate the respect for law among young Fijians and encourage criminality. Some urged that the bitterly opposed Prime Minister and Leader of the Opposition set an example to the country by reconciling with each other. Attorney General Bale insisted the Bill would not entail a general amnesty for coup prisoners, arguing that the statute of limitations had passed for conviction on treason charges. This was inaccurate; the Bill was quite explicitly intended to apply retrospectively to those already convicted of treason, subject to satisfying the other conditions for amnesty. 
The extra-parliamentary mobilization for and against the Bill continued as the Law and Justice Committee commenced its proceedings. The NGO Coalition on Human Rights launched a campaign encouraging people to wear yellow ribbons to show opposition to the Bill. Another NGO, the Citizens' Constitutional Forum, hung a giant yellow ribbon at the gate to their office and Bernadette Rounds Ganilau (interim Assistant Minister for Women in 2000-2001) unfurled and pinned up a giant yellow ribbon at the entrance to her home. In response, the SDL launched a rival campaign encouraging supporters of the Bill to wear blue ribbons. Blue ribbon committee advisor and Assistant Minister for Women (2005) Losena Salabula claimed that the majority of Fiji citizens, regardless of ethnic background, supported the Bill. ${ }^{75}$ The blue ribbon campaign proved a potent means of gearing up the SDL party machinery, and particularly the SDL women's organizations, for the 2006 election.

\section{The Joint Parliamentary Sector Committee}

The Joint Parliamentary Sector Committee on Justice, Law and Order received 272 formal written and oral submissions. The strong demand for wide consultation resulted in many extensions of the original deadline for submissions. ${ }^{76}$ The Bill was translated into Fijian and Hindi, and public hearings were held in the Central, Northern, Western and Eastern Divisions. Formal submissions were received from the disciplinary forces (police and military), political parties (SDL, FLP, NFP, National Alliance Party of Fiji (NAPF)), four trade unions, 21 religious organizations,${ }^{77} 20$ Fijian organizations, ${ }^{78}$ six NGOs, the Director of Public Prosecutions, the Fiji Human Rights Commission, the Fiji Law Society, the Fiji Women Lawyers Association, seven women's organizations, and from other professional groups. The Committee received 124 formal written and oral submissions, and another 148 submissions were presented orally during public hearings by individual groups and organisations. ${ }^{79}$ Interestingly, the Muslim religious organizations did not make any submissions on the Bill, an absence that indicated some notable accommodation by some leaders with the SDL government. The FLP did not attend any of the meetings of the committee in the wake of their parliamentary walkout on 2 June.

In his report to parliament, presented on 1 December 2005, the committee chairperson, the Hon. Manasa Tugia, observed that villages and tikinas 
throughout the country supported the Bill. The report noted, however, that some of these views were expressed by people who had not actually read the Bill and were focused rather broadly on the need for reconciliation and unity. ${ }^{80}$ Supporters of the Bill often saw such legislation as a vehicle by which to resolve the inter-ethnic tensions, put an end to conflict and upheavals in Fiji and promote genuine and lasting national unity. This, many said, could only be achieved through a biblically and spiritually based process of reconciliation, tolerance and understanding, and by use of the concept of restorative justice. Merely allowing normal judicial processes to take their course, it was argued, would not stop the kinds of events that occurred in 1987 and 2000 from recurring; the root causes of the problem, and the unresolved issues for both the indigenous and non-indigenous communities needed to be fully addressed. ${ }^{81}$

As part of the consultation process, deliberations concerning the Bill occurred in Fiji's 14 provinces. The Prime Minister and key cabinet members visited rural areas to encourage support for the Bill. Some NGOs sought to attend those meetings. The Lomaiviti Provincial Council was one which did not allow NGO representatives to speak at their one-day meeting in Levuka on 30 June 2005; Roko Tui Lomaiviti Ratu Filimoni Baleimua said only provincial council members were allowed to attend. ${ }^{82}$ Kadavu was the first province to give approval to the Bill at a provincial council meeting on the island of Tavuki. Council Chairman Ratu Josateki Nawalowalo said the way forward for Fiji was to express support for the government's initiative. Initial reservations about the amnesty clause were allayed by Attorney General Bale. ${ }^{83}$

The Lau Provincial Council was the last of the 14 provinces to endorse the Bill.

Adi Koila Nailatikau, daughter of the late President Ratu Mara and a member of Fiji's Senate, condemned the RTU Bill saying 'reconciliation cannot eventuate...until the proper legal procedures have been followed'. Adi Koila said genuine forgiveness would not be forthcoming until the truth about who was involved and who funded the coup was known; she blamed the 2000 political events for contributing to her father's grief, leading to his death on 18 April 2004. ${ }^{84}$ Adi Koila believed most members of the Lau Provincial Council - especially at the grass roots - did not understand the amnesty clause. The ex-minister and representative from Lakeba, Filipe Bole, opposed 
the Bill, saying the word 'truth' should also be included so that investigations would become meaningful and useful, and urging that the amnesty clause be refined. ${ }^{85}$ But these two urban Lauans were unable to prevail on their island kinsfolk. The Lau Provincial Council decided to support the Bill, expressing a desire to move forward through the intended government-ordained process of reconciliation.

Following the endorsement by all 14 provincial councils, Fiji's Great Council of Chiefs - the Bose Levu Vakaturaga - convened, and endorsed the Bill on 28 July 2005; however, it urged the government to consider the concerns raised by the army and others. ${ }^{86}$ The Bill was also endorsed by the Council of Rotuma, the Rabi Island Council, the Taukei Movement, the Fijian Dockworkers and Seafarers Union, the Methodist Church, the Assembly of Christian Churches in Fiji, the Fiji Institute of Research and Education, and the Fijian Teachers Union. It had the support of coup-related prisoners. Josefa Nata and Timoci Silatolu made submissions supporting the Bill. Oddly, both of these imprisoned coup-leaders sought to emphasize the importance of truth-telling, and struck a somewhat conciliatory tone. For Ratu Silatolu:

The Bill will allay the fears of the RFMF; the fact that full disclosure is part of the amnesty provision...will enable everyone to tell the truth... The Bill will enable perpetrators to personally seek reconciliation through an arbiter otherwise the issue of 2000 will be used as a political tool when there is no closure... The concept of veisorosorovi or asking of forgiveness does not discount punishment; the seeking of forgiveness is still applicable. ${ }^{87}$

In his submission, Josefa Nata, who was also serving a life sentence for his part in the coup, stated:

Drop the amnesty clause and make truth telling through a Truth Commission ...the main focus of the Bill. The Commission should have an investigation adjunct to look into evidence that could not be verified through hearing. ${ }^{88}$

Those who opposed the Bill emphasized dangers associated with the amnesty provisions, and the likelihood that these would legitimize the type of Fijian extremism that had so damaged the country in 1987 and $2000 .{ }^{89}$ The Group of Concerned (Fijian) Mothers circulated a petition rallying opposition to the Bill and attracted 25,706 signatures [as at 26 July 2005] of which 20,672 were Indians, 4,903 Fijians and 131 others. ${ }^{90}$ The National Council of Women and the Fiji Association of Women Graduates protested that the Bill lacked 
provisions for gender equality. The Fiji Women's Rights Movement suggested that the Bill was biased in favour of ethnic Fijians and discriminated against non-indigenous Fijians because the majority of those eligible for amnesty would inevitably be indigenous Fijians.

In its final report, the Joint Parliamentary Sector Committee on Justice, Law and Order indicated concern that the draft Bill did not make clear what categories of crime would be considered as acts associated with 'political objectives'. The Committee rejected concerns about the constitutional implications of the Bill, about the possibility that entrenched powers of the judiciary might be usurped and about the likelihood of a post-passage legal challenge to the Bill. It stressed that there should be no interference with the courts' deliberations and that only afterwards should any RTU Bill-related considerations of restorative justice be entertained. ${ }^{91}$

After weighing up submissions and general public reactions, the committee recommended that the government 'slightly readjust the way in which the Bill is designed, whilst still maintaining the basic objective and the conceptual framework of the Bill'. In concession to the critics, the committee concluded:

The Bill also needs to be consistent with the existing statutory powers of stakeholders, like the Police, DPP and the Fiji Human Rights Commission. The Bill must in no way be, or be seen as to compromise or to undermine, the integrity and independence of the judiciary and these other constitutional offices. Any adjustments to the Bill must comply with the law. ${ }^{92}$

The committee also suggested limiting the scope for reference to the Reconciliation and Unity Commission. Serious acts associated with the political and civil unrest, such as loss of life, grievous bodily harm, and offences against public order would, it was suggested, be referred to and processed by the courts. Amnesty should not be extended to those found guilty of murder, rape and other sexual offences. Where those given amnesty by the commission failed to obey any conditions set down, this would be regarded as an offence that could be prosecuted in court. The Bill did not intend, it was suggested, to provide any blanket amnesty to free persons already convicted for coup-related offences, neither did it aim to free those already charged or to be charged. As if to emphasize the likely limitations of such legislation in terms of practical 
impact, the committee pointed out that, in South Africa, of the 70,000 amnesty applications made to the Truth and Reconciliation Commission only 7,000 or 10 per cent were successful..$^{93}$

These deliberations of the Joint Parliamentary Sector Committee on Justice, Law and Order largely escaped public attention, and the national debate remained starkly polarized despite the more cautious views expressed by the committee itself. The fairness of these deliberations and the sensible character of the conclusions surprised many, particularly given the chairmanship of CAMV parliamentarian, Manasa Tugia. That such measured advice came from a representative of the party representing the more militant wing of indigenous Fijian opinion perhaps eased the pressure on the government, and made the passage of the Bill less urgent for electoral purposes for the Qarase government.

\section{The impact of the RTU Bill on the 2006 election}

The election was held over the period 6-13 May 2006, eleven and half months after the Bill had first been introduced on the floor of the House. The intervening period had proved an era of controversy, an era of FLP boycott of parliament and military threat of insurrection. Yet the Bill had nevertheless played the politically useful role of enabling the SDL to rally Fijian support. Messages of 'forgiveness' and 'reconciliation' had played to perceptions of Christian moral righteousness about the RTU Bill. Indo-Fijian politicians also recognized something of the political role being played by the RTU Bill. FLP parliamentarian Ganesh Chand claimed in late 2005 that the Bill was part of a fear campaign politicians were running for the next year's general election - fear was being instilled in people over the RTU Bill, as well as the land and gay rights ${ }^{94}$ issues. $^{95}$

In the highly polarized election that was to ensue in May 2006, the RTU Bill proved, for the governing SDL, a vehicle for mobilizing Fijian support. The Labour Party's opposition - through boycotts and its refusal to enter into dialogue with the SDL - was portrayed as indicative of a hostile attitude towards the concerns of the vanua. Yet it was not so much the Labour Party's opposition that inflamed the Fijian voters as the military's implacable hostility to provisions that it felt would seriously undermine the rule of law. Fijians in many quarters 
appeared alarmed by the military's interference in the political process and by the RFMF's open condemnation of the Fijian-dominated government. The military's 'truth and justice' campaign thus received a hostile reception from many Fijians. Some provinces went so far as to tell the military that soldiers were not welcome in their village or province (see Ratuva, this volume).

Commander Bainimarama's criticisms of the Bill were used during election campaigns by both major political parties. The SDL portrayed the commander as supporting Mahendra Chaudhry's bid to return as prime minister, reviving longstanding Fijian fears about having an Indo-Fijian leader. Qarase emphasized on the campaign trail that Fiji was not ready for an Indo-Fijian prime minister and how important it was that Fijians ensure that the SDL win by giving them first preference votes. He portrayed the SDL as safeguarding Fijian interests through affirmative action programs, the Qoliqoli Bill, and the progress in converting crown land into native land. The Prime Minister capitalized on Chaudhry's support for Bainimarama's outbursts by claiming this indicated Labour Party support for an illegal takeover of the government by the military. ${ }^{96}$

For the FLP, the commander's outbursts were indicative of the military's firm intention to uphold the rule of law and protect the 1997 constitution. On the campaign trail, mention of Bainimarama's strong stance against the SDL government was used to allay fears that the re-election of a Labour government might lead, yet again, to a coup. The military, it was said, clearly intended to uphold the authority of the legitimately elected government. For the FLP, the RTU Bill also proved a means of rallying a broader-based oppositional coalition. Back in 2001, it had been left in a marginalized position, without the broad-based coalition it had relied upon to achieve power in 1999. The 'moderates forum' parties had favoured the SDL over the FLP, ensuring that the FLP could not win in the marginal open constituencies. The RTU Bill had so inflamed moderate opinion, particularly among the general voters but also among National Federation Party supporters, that the FLP stood a better chance of attracting moderate support than in 2006 than in 2001, although, as it turned out, the moderate parties proved unable to command a substantial share of the national vote.

The RTU Bill also proved important for the SDL's relationship with its 
coalition partner, the CAMV. In the years after the 2001 election, CAMV ministers had been drifting towards the larger and better-financed SDL. Without the intervention of the courts, Ratu Naiqama Lalabalavu and his colleagues would, in all probability (even without the RTU Bill), have contested the 2006 election as SDL candidates. The coup-related trials proved a millstone round the neck of this accommodation. They fuelled the objections of radicals at the grass roots of the party that the SDL had done little for the indigenous cause during its term in office. The RTU Bill thus played a potent ideological role: it convinced many of the CAMV rank-and-file that the SDL was sincere in its attempt to pardon the coup-related prisoners. It reassured key CAMV leaders that their interests and ideology would be looked after by the SDL and demonstrated that the two parties were basically on the same side. That SDL vice president Ratu Inoke Takiveikata remained in prison on mutiny-related charges also reassured the CAMV that harsh prison terms were not biased against their own party leaders.

In fact, the coup trials proved a double-edged sword for the CAMV; while they inflamed radical passions on the one hand, on the other they caused financial embarrassment for the party. The CAMV had an opening balance of over $\$ 36,000$ on 26 May 2004; notably, this was boosted to over $\$ 50,000$ by a $\$ 15,000$ donation by the SDL in July $2004 .{ }^{97} \mathrm{~A}$ little over $\$ 31,000$ was spent on legal fees for party members from 8 July 2004 to 6 May 2005, including costs for the cases of Sports Minister Isireli Leweniqila, party trustee Metuisela Mua, and former MP Peceli Rinakama, and for the appeal for gaoled former deputy speaker Ratu Rakuita Vakalalabure. ${ }^{98}$ As a result, the CAMV was cashstrapped, and had insufficient funds to contest the 2006 poll. Its leaders, in particular, urgently desired a cosy ride back into cabinet as part of the SDL. The RTU Bill placated the radical fringes, and promised something to the prisoner fraternity. This eased the inevitable transition. CAMV parliamentary leader Ratu Naiqama fended off opposition to CAMV's merger with SDL by insisting that the party had become impoverished because members had failed to contribute sufficiently. When the CAMV dissolved itself at its AGM on 17 February 2006, it had a closing balance of a little over $\$ 3,000$. The merger with SDL took place that same night at a traditional ceremony held at Tamavua village, the birthplace of SDL. ${ }^{99}$ 


\section{Conclusion}

The RTU Bill was temporarily shelved in February 2006 because, so it was announced, the government did not have enough time to make the necessary amendments prior to the May 2006 election. ${ }^{100}$ This was a strange decision given the electoral importance initially attached by SDL leaders to securing the passage of the Bill. SVT spokeswoman Ema Druavesi criticized the consultation exercise as a huge waste of taxpayers' money. ${ }^{101}$ That was undoubtedly true, but from the SDL vantage point it seems reasonable to conclude that the Bill had achieved key objectives, even without passing into law. It had warded off the threat of a split in the governing coalition occasioned by the CAMV's announcement that it intended to table its own Bill in parliament for the release of prisoners. It had paved the way for a smooth liquidation of the CAMV, and for the Vanua Levu and Northern Tailevu ministers to contest under the SDL banner - a situation that provided the SDL with a crucial five extra seats at the 2006 election, giving the party an absolute majority in parliament. ${ }^{102}$ Whether or not this was the original intention is questionable. More likely, political recognition that solid strategic advantages could be obtained even without passage of the Bill only became obvious in early 2006.

The SDL did not make a great play of the RTU Bill in the weeks immediately prior to the election. In its 32-page manifesto, 'reconciliation and unity' featured on the last page. SDL policy in this respect was described as based on internationally acclaimed principles of 'restorative justice' and it was made clear that the government intended to introduce 'amendments based on wide public consultation' and legislation that was 'consistent with the constitution'. Yet the nature of those amendments was, perhaps unsurprisingly, not made clear. Had big concessions to the opposition been announced, this might have generated disillusionment among the former rank-and-file in the CAMV. Had the government remained firm and insisted on passage of the draft Bill unchanged, it might have alienated moderate public support for the governing party and generated further instability in relations with the security forces. The tactically astute option was to shelve the Bill, and instead make vague public pronouncements about future intentions.

Nevertheless, over the longer run, the Bill had played a potent electoral role in 
inflaming racial emotions and polarizing voters during the year prior to the 2006 poll. The amnesty clause automatically drove the Indo-Fijian community against the Bill. Outright rejection by the Indo-Fijian political leaders of government proposals for reconciliation had been matched by an extraordinary mobilization of support for the Bill from the Methodist Church, provincial councils and the Great Council of Chiefs. Since this had become such a pivotal plank of government policy, it ultimately proved a powerful vehicle for consolidating support behind the SDL. Ethnic polarization, exacerbated by the controversy over the RTU Bill, was nurtured during the 2006 election campaign by use of the familiar 'us and them' rhetoric to incite racial fears. The oppositional stance of the military only contributed to that electoral polarization. Through mobilizing ethnic Fijian voters in this way, the SDL not only achieved its merger with the CAMV, but also secured an absolute majority in the post-election parliament, and left the FLP confined to its majority Indo-Fijian strongholds in the west and north of the country and unable to build strong alliances across the ethnic divide. For these reasons, the sentiments expressed by Attorney General Bale, as cited at the start of this chapter - that the electoral fortunes of the SDL and the fate of the RTU Bill were inextricably linked - proved accurate, even though the Bill was put into cold storage for the duration of the campaign. Whether or not the RTU Bill, which would potentially cost the country millions of dollars in compensation and would continue to exacerbate communal tensions, is useful or suitable given the new post-election multiparty cabinet setting is much more doubtful.

\section{Notes}

1 The Fiji Times, 16 June 2005, p.1.

2 Promotion of Reconciliation, Tolerance and Unity Bill, full text reproduced in The Sunday Times, 15 May 2005, under the title 'Unity - or more Division?'.

3 George Speight was convicted of treason and sentenced to death by hanging on 18 February 2002. However, the death penalty was commuted to a life sentence after a request by Attorney General Qoroniasi Bale to the Prerogative of Mercy Commission. As a result, Speight was still, at the time of the 2006 election, serving a life imprisonment term on the island of Nukulau, off Suva. The death penalty was abolished the day after the decision of the Prerogative of Mercy Commission.

4 Radio Fiji News, 1 May 2005 (Pacific Islands Report archives).

5 Matanigasau: a traditional Fijian ceremony to ask for forgiveness (Macquarie Dictionary of English for the Fiji Islands, 2006). Veisorosorovi: a ceremony that provides a means of 
community peace-building and conflict resolution. It comes from the word soro, meaning to humble oneself, surrender or ask for forgiveness while admitting fault. Veisorosorovi is a reciprocal process and is more effective in addressing conflicts between groups (Ratuva, $\mathrm{S}$. 2003. 'Reinventing the cultural wheel: reconceptualising restorative justice and peace building in ethnically divided Fiji', in S. Dinnen, A. Jowitt \& T.N. Cain (eds). A Kind of Mending: Restorative Justice in the Pacific Islands, Pandanus Books, Canberra.

6 Hon. Qarase, Statement on Reconciliation and Justice, 5 May 2005, media briefing, 4 May 2005.

7 'Pardon Me: What is Fijian Reconciliation and Restorative Justice?', opinion article by Jone Dakuvula, 5 November 2005, <www.ccf.org.fj>. The Fiji Times, 5 October 2004, p.1.

9 PINA Nius Online, 20 May 2000.

PINA Nius Online, 24 May 2000.

PINA Nius Online, 20 May 2000.

PINA Nius Online, 20 May 2000.

Fiji Sun/Radio Fiji/Pacific Nius/Niuswire, 27 July 2000.

Fiji Sun/Radio Fiji/Pacific Nius/Niuswire, 27 July 2000.

Fiji Times/Fiji Sun/Pasifik Nius/ USP Journalism students, 7 November 2000.

Fiji Sun, 6 August 2004. Youth Minister Isireli Leweniqila was acquitted.

Fiji 1 News, 9 August 2004.

The Fiji Times, 26 August 2004.

The Fiji Times, 27 January 2005.

The Fiji Times, 11 April 2005.

Fijilive.com, 5 September 2005.

Fijilive.com, 10 August 2005.

Hon. L. Qarase, 'Summary of Remarks for New Reconciliation Legislation', 5 May 2005, $<w w w . f i j i . g o v . f j>$.

The six CAMV MPs who won seats at the 2001 election were George Speight, Isireli Leweniqila, Manasa Tugia, Ratu Naiqama Lalabalavu, Josateki Vula and Ratu Rakuita Vakalalabure. Apart from Josateki Vula, all CAMV MPs were charged for coup-related offences. Isireli Leweniqila was acquitted. Speight lost his seat after failing to attend consecutive sittings of the House because he was in prison, but his brother Samisoni Tikoinasau (CAMV) won the consequent by-election. Ratu Rakuita also lost his Cakaudrove seat after conviction, but this was taken by fellow CAMV member Niko Nawaikula in the resulting by-election.

Fijivillage.com, 30 June 2005.

The Fiji Times, 6 August 2004, p.3.

The Fiji Times, 6 August 2004, p.3.

Fijilive.com, 7 April 2005.

Fijilive.com, 7 April 2005.

The Fiji Times, 23 June 2005.

Fiji 1 News, 21 September 2005.

Fijilive.com, 5 September 2005.

Parliament of Fiji, Daily Hansard, 18 November 2005.

Fiji Sun, 30 August 2006. 
The Fiji Times, 22 February 2006.

The Fiji Times, 16 June 2005.

Report of the Sector Standing Committee on Justice, Law and Order on the Promotion of Reconciliation, Tolerance and Unity Bill, November/December 2005, p. 27.

Fijivillage.com, 20 June 2005.

Fijilive.com, 2 August 2005.

The Fiji Times, 2 October 2005.

The New Zealand Herald, 10 June 2005, <www.nzherald.co.nz>.

Fijilive.com, 31 May 2005.

The Fiji Times, 21 June 2005.

Fijivillage.com, 28 June 2005.

Fijivillage.com, 27 June 2005.

Scoop, 24 June 2005, <www.scoop.co.nz>.

The Fiji Times, 31 May 2005.

The International Bar Association, 2 February 2006, <www.ibanet.org>.

Fijilive.com, 13 July 2005.

Fijilive.com, 30 January 2006.

Fiji Sun, 30 January 2004.

Fijilive.com, 14 April 2005.

Fijilive.com, 5 January 2005.

Report of the Sector Standing Committee on Justice, Law and Order on the Promotion of Reconciliation, Tolerance and Unity Bill, November/December 2005, p.44.

Fijilive.com, 30 Janury 2006.

Fijilive.com, 13 July 2005.

The Fiji Times, 2 October 2005.

Section 112 of the 1997 constitution, confirms that the '...Republic of Fiji Military Forces established by the Constitution of 1990 continues to exist', but the section also states that 'Parliament may make laws relating to the Republic of Fiji Military Forces', and that the exercise of military executive control by the commander is '...subject to the control of the Minister' (chapter 7, section 112, p.111, Constitution (Amendment) Act 1997 of the Republic of Fiji Islands, 25 July 1997). Section 110 of the 1997 constitution makes it clear that the military and police are not to be regarded as government departments and therefore do not fall within the ambit of the Secretaries of Ministries (section 110, 1997 constitution of Fiji, p.110).

Fijivillage.com, 22 June 2005.

Fijivillage.com, 30 June 2005.

Fijilive.com, 17 January 2006.

Fijivillage.com, 20 June 2005.

Fijivillage.com, 30 June 2005.

The Fiji Times, 1 June 2005, p.1.

See Parliament of Fiji, Daily Hansard, 31 May 2005.

Fijilive.com, 16 May 2005.

Parliament had been re-located temporarily to allow repairs to the leaking roof of the normal chamber up at Veiuto.

The Fiji Times, 4 June 2005, p.7. 
70 The previous chairperson had been Ratu Rakuita, but after his conviction in August 2004, the Parliament's secretary general, Mary Chapman, had revealed his replacement would have to be a CAMV MP (The Fiji Times, 25 August 2004, p.3).

71 'Bill will promote instead of Forcing Unity - Bale', Fiji Government Online, media release, 19 May 2005.

72 'No general amnesty - PM reiterates', Fiji Government Online, media release, 22 July 2005.

73 'Proposed bill would determine the reasons for coups - PM', Fiji Government Online, media release, 26 July 2005.

74 'Bill to be discussed at the Ministry's workshop in Labasa tomorrow', Fiji Government Online, media release, 14 July 2005.

75 Fijilive.com, 21 June 2005.

76 From 17 June 2005 to 31 July 2005 and then to 30 September 2005. Including Christian and Hindu organizations, and the Fiji Kisan Sangh.

Including the Bose Levu Vakaturaga (Great Council of Chiefs), Rotuma and Rabi Councils, Viti Cauravou, provinces and villages and the Fijian Institute of Research and Education. Report of the Sector Standing Committee on the RTU Bill, November/December 2005, p.16.

80 Hon. Tugia - Presentation of the Committee's Report on the RTU Bill (Bill No. 10 of 2005). 1 December 2005. The committee noted a Tebbutt Times Poll conducted in early June 2005 had been based on a sample of 1008 adults in Suva, Lami, Nausori, Nadi, Lautoka and Ba. Of these, 80 per cent had not read the Bill (p.43).

81 Report of the Sector Standing Committee on Justice, Law and Order on the Promotion of Reconciliation, Tolerance and Unity Bill, November/December 2005. Fijivillage.com, 29 June 2006. Fijilive.com, 27 June 2005.

The Fiji Times, 23 October 2004. The recent passing of Adi Koila's father, Ratu Mara, was followed by that of her mother, Roko Tui Dreketi Adi Lala Mara, a few months later. The Fiji Times, 26 July 2005.

The Fiji Times, 29 July 2005.

Report of the Sector Standing Committee on the RTU Bill, Nov/Dec 2005, pp.183-84.

Report of the Sector Standing Committee on the RTU Bill, Nov/Dec 2005, p.182.

The following organizations largely opposed the Bill because of its amnesty provisions, its contravention of human and legal rights, and its protection of criminals which could breed terrorism, increase political instability and could lead to further coups: the Fiji Human Rights Commission, the Fiji Police Force, the Republic of the Fiji Military Forces, the Director of Public Prosecutions, the Fiji Law Society, the Fiji Labour Party, the National Federation Party, the National Alliance Party, the Roman Catholic Church, the Anglican Church, the Fiji Baptist Convention, the Seventh-Day Adventist Church, St Andrews Presbyterian Church, the Anglican Mission District, the Interfaith Search Fiji, Pasifika Communications, the Ecumenical Centre for Research, Education and Advocacy, the Fiji Trade Union Congress, the Pacific Concerns Resource Centre, the Fiji Institute of Accountants, the Fiji Women's Rights Movement, the Fiji Women's Crisis Centre, the Shree Sanatan Dharm Pratinidhi Sabha Fiji, the Kisan Sangh, and the Then India Sanmarga Ikya Sangam. 
90 Report of the Sector Standing Committee on the RTU Bill, November/December 2005.

91 Report of the Sector Standing Committee on the RTU Bill, November/December 2005.

92 Report of the Sector Standing Committee on the RTU Bill, November/December 2005, p.27.

93 Report of the Sector Standing Committee on the RTU Bill, November/December 2005, p.31.

94 Politicians and Methodist Church factions had been organizing protests against gays as 'unChristian'.

95 Fiji 1 News, 21 November 2005.

96 The Fiji Times, 17 January 2006.

97 Fijilive.com, 19 February 2006.

98 Fijilive.com, 19 February 2006.

99 Fijilive.com, 19 February 2006.

100 Fiji Sun, 9 February 2006.

101 Fiji Sun, 9 February 2006.

102 These five crucial seats are those of Isireli Leweniqila - Macuata Fijian Provincial; Niko Nawaikula - Cakaudrove West Fijian Provincial; Ratu Naiqama Lalabalavu - Cakaudrove East Fijian Provincial; Samisoni Tikoinasau - Tailevu North Fijian Provincial; and Ratu Josefa Dimuri - Bua/Macuata West Open. 